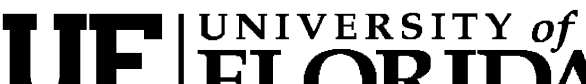 FLORIDA \\ IFAS Extension
}

\section{Blossom-End Rot in Bell Pepper: Causes and Prevention'1}

\section{George J. Hochmuth and Robert C. Hochmuth ${ }^{2}$}

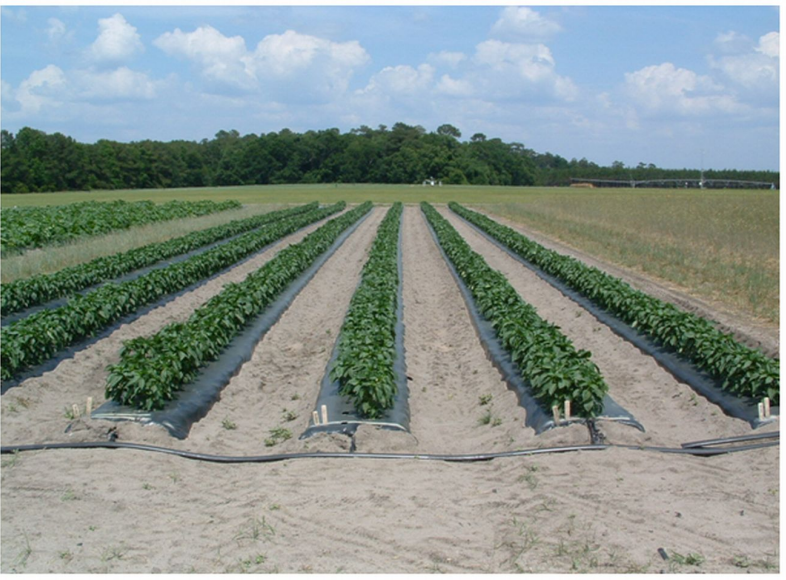

Young pepper crop on black-plastic mulched beds with drip irrigation at the North Florida

Research and Education Center-Suwannee Valley, in Live Oak, Florida.

\section{Introduction}

Bell pepper is a major vegetable crop in Florida, grown on nearly 20,000 acres with a total value of nearly $\$ 200$ million. Pepper is subject to many biotic diseases, caused by fungi, bacteria, and viruses, and to several abiotic or physiological disorders, such as nutrient deficiencies. One of the most commonly observed disorders of pepper is blossom-end rot
(BER) which can cause major crop loss. This fact sheet describes BER, its causes, and prevention.

\section{Symptoms}

Calcium $(\mathrm{Ca})$ is a required element for plants to grow normally and complete their life cycle, producing fruits and seeds. Calcium ions are present in the soil solution in which the pepper roots are growing. Blossom-end rot results from a calcium (Ca) deficiency in young, rapidly expanding pepper fruit tissues.

Blossom-end rot symptoms begin as a light green or yellow-colored sunken spot and expand to a larger collapsed area that begins to turn black from colonization typically by saprophytic Alternaria fungal species. BER-affected fruits tend to turn color prematurely from green to brown and then red (or yellow if yellow is the mature color of the variety in question). Large BER spots can be subject to infection from soft-rot bacteria.

\section{Calcium physiology}

To understand blossom-end rot causes and control, we need to understand some basic information about Ca uptake from the soil and its

1. This document is SL 284, one of a series of the Soil and Water Science Department, Florida Cooperative Extension Service, Institute of Food and Agricultural Sciences, University of Florida. Original publication date April 2009. Visit the EDIS Web Site at http://edis.ifas.ufl.edu.

2. George J. Hochmuth, professor, Department of Soil and Water Science; Robert C. Hochmuth, multi-county extension agent, North Florida Research and Education Center (REC)--Live Oak FL; Florida Cooperative Extension Service, Institute of Food and Agricultural Sciences, University of Florida, Gainesville, FL 32611.

The Institute of Food and Agricultural Sciences (IFAS) is an Equal Opportunity Institution authorized to provide research, educational information and other services only to individuals and institutions that function with non-discrimination with respect to race, creed, color, religion, age, disability, sex, sexual orientation, marital status, national origin, political opinions or affiliations. U.S. Department of Agriculture, Cooperative Extension Service, University of Florida, IFAS, Florida A. \& M. University Cooperative Extension Program, and Boards of County Commissioners Cooperating. Millie Ferrer, Interim Dean 


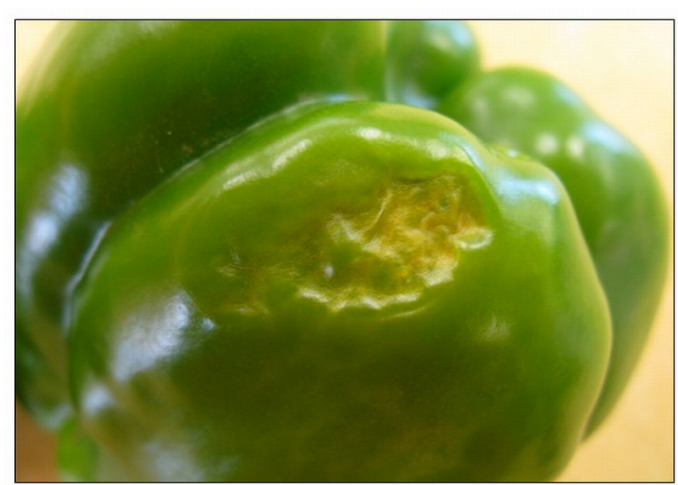

Figure 1. Early tissue breakdown and symptoms of BER. Credits: Bob Hochmuth

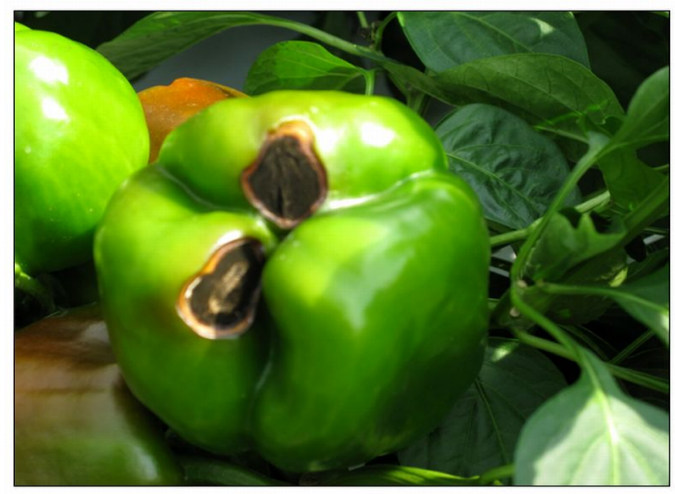

Figure 2. Advanced BER of pepper fruits in the field. Saprophytic Alternaria spp. grow on the BER lesions causing the black coloration. Credits: Bob Hochmuth

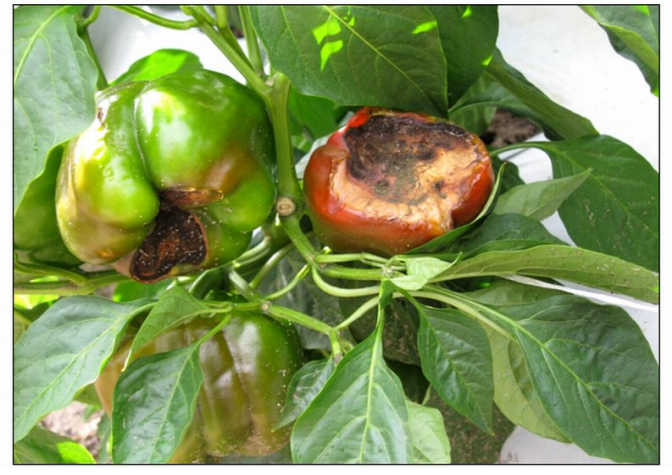

Figure 3. Advanced BER symptoms on pepper fruits on the plant showing premature coloration. Credits: Bob Hochmuth

transport and function in the plant. Calcium deficiency in the fruits results from two types of problems in Ca delivery to the plant. First, there could be an inadequate concentration of $\mathrm{Ca}$ in the soil solution. Second, there could be inadequate concentrations or amounts of $\mathrm{Ca}$ being delivered to the rapidly growing tissues, such as leaves or fruits. Calcium undergoes various reactions in the soil such that $\mathrm{Ca}$ is removed from the soil solution by

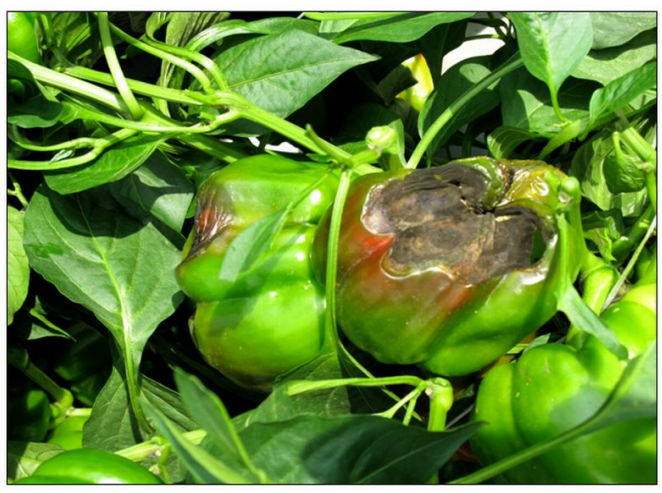

Figure 4. Advanced BER accompanied by secondary bacterial soft rot (shiny areas at the margins of the BER lesions). Credits: Bob Hochmuth

precipitation or added to the solution as the $\mathrm{Ca}$ minerals in the soil or calcium fertilizer dissolves. Soils under regular vegetable production usually contain enough $\mathrm{Ca}$ for normal crop growth; typically other factors, explained below, lead to BER.

Plant root morphology plays an important role in Ca nutrition of the plant. Nearly all of the $\mathrm{Ca}$ is taken up by the plant by the young root tips, perhaps most in the newest one inch of the root tip. In older portions of the root, the cells in the endodermal layer are surrounded by a layer of suberin on their radial and transverse walls, called the Casparian strip (Figure 5). Calcium in the soil solution is taken into the pepper root tips by a passive uptake process. Passive uptake means the plant expends no energy to take $\mathrm{Ca}$ into the plant. The $\mathrm{Ca}$ ion does not pass actively across a cell membrane as phosphorus, nitrogen, and potassium do but rather moves in the water solution in the intercellular spaces between root cells and then across the root, following the flow of water, and then into the xylem vessel. The Casparian strip, in the older portions of the root, prevents the lateral, passive movement of water and ions toward the xylem. The xylem vessel is the water conducting tissue ("tubes") that moves water containing $\mathrm{Ca}$ ions to the top of the plant.

Calcium ions mostly move with the water in the transpiration stream, up the xylem vessel, toward the upper plant parts. Water is moved up the stem as water is lost (transpired) from leaves. Transpiration is the process by which plants lose water from plant organs such as leaves and fruits. Water is lost from the surface of leaves through special openings called 


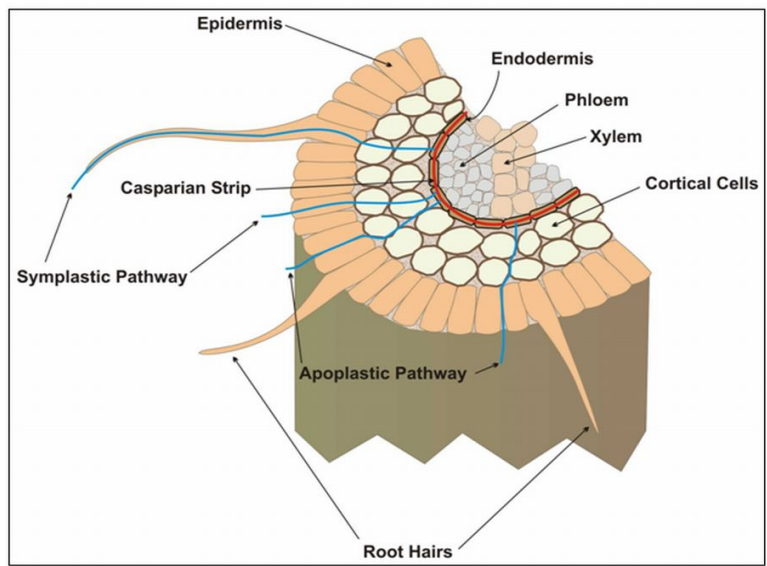

Figure 5. Cross section of a root showing the Casparian strip and symplastic (active) and apoplastic (passive) ion uptake across the root. Ca uptake is most effective in younger root tips, where the Casparian strip is not fully developed. Credits: Greg Means and George Hochmuth

stomata. More water from the xylem stream replaces water that is transpired. Transpiration is the main pathway by which $\mathrm{Ca}$ ions reach young growing leaves, stems, and fruits. Another mechanism for $\mathrm{Ca}$ to reach the tops of plants is by "root pressure" where roots, water, and $\mathrm{Ca}$ ions are forced up the xylem under conditions of low transpiration, such as during the night, when relative humidity is high. Growers should make sure there is ample soil moisture at night, since root pressure can serve as a major mechanism to get $\mathrm{Ca}$ ions into fruits.

Calcium is required in cell wall development in actively dividing and expanding cells. Calcium also is required in calcium pectate which is part of the middle lamella that "glues" cells together forming tissues (Figure 6). Under Ca deficiency, cells and tissues collapse, leak cell fluids, and die. This death of cells and tissues leads to the typical collapsed and sunken areas on the tip, or the blossom-end area of young, rapidly growing fruits.

In most BER cases in Florida, it is the relationship between $\mathrm{Ca}$ movement in the plant and transpiration in leaves that is most likely the basis for $\mathrm{Ca}$ deficiency in fruits. Calcium moves with the transpiration stream, therefore, most $\mathrm{Ca}$ will be transported to those organs with the greatest transpiration rate. The organs with the greatest transpiration rate are large, rapidly expanding leaves because these organs have the greatest concentration of fully developed stomata. In addition, there is a less developed waxy cuticle covering the epidermal cells at the surface of the leaf, compared to older leaves. The cuticle reduces water evaporation from the surface of the leaf.

Rapidly growing pepper fruits do not transpire as much as leaves do, and fruits have a waxy covering that prevents water loss. Low transpiration and evaporation rates in the fruits means less $\mathrm{Ca}$ transported to the fruits. These characteristics place fruits at a distinct disadvantage in competing for $\mathrm{Ca}$ ions as they are transported in the plant. Any plant growth and developmental factors that tip the balance of Ca transport in favor of leaves will predispose fruits to Ca deficiency, potentially leading the BER. BER is typically most prevalent on the earliest fruits on the plant ("crown fruits"), because there is the greatest ratio of leaf surface area to fruit surface area at this growth stage. Although early fruits are most vulnerable to $\mathrm{Ca}$ starvation compared to fruits that set later in the growth cycle of the plant, periodic BER can be manifest at any time given certain situations described below.

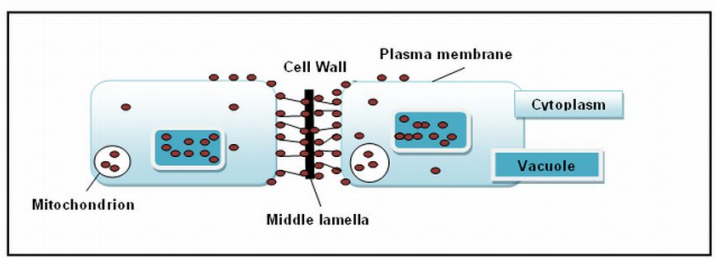

Figure 6. Neighboring cells depicting Ca distribution. Credits: Greg Means and George Hochmuth

\section{Calcium deficiency}

Calcium in the soil solution comes from several native mineral sources in the soil, such as calcium carbonate (limestone), apatite (calcium phosphate), and gypsum (calcium sulfate). These minerals are sometimes added as fertilizer. Growers also can supply $\mathrm{Ca}$ fertilizer sources such as calcium nitrate, calcium chloride, or various chelated calcium fertilizer materials. These fertilizers are often applied through a drip irrigation system to supply $\mathrm{Ca}$ to the root zone. Some soils should not require $\mathrm{Ca}$ fertilization. For example, soils with large amounts of calcium carbonate are likely to have ample $\mathrm{Ca}$ ions in the soil solution. This situation would occur where soils contain marine shells or are coral soils such as 
those used for vegetable production in the Homestead, Florida area.

Another source of $\mathrm{Ca}$ ions is the well water used for irrigation. In Florida, well water comes from the Floridan aquifer which is located in the limestone rock underlying most of Florida. Water pumped from this aquifer will contain significant concentrations of $\mathrm{Ca}$, often on the order of 100 parts per million. This concentration is similar to concentrations of $\mathrm{Ca}$ in many recommended hydroponic nutrient solutions. Low-Ca irrigation water would be rare in peninsular Florida.

Inadequate $\mathrm{Ca}$ in the soil solution can be confirmed with a soil test, such as the Mehlich-1 soil test. A Mehlich-1 soil test index of 300 parts per million or greater indicates adequate concentrations of $\mathrm{Ca}$ in the soil. General knowledge about the soil chemistry in the field also can help predict $\mathrm{Ca}$ availability levels for the crop.

\section{Factors predisposing fruits to BER}

There are plant factors that can increase the likelihood of BER. Growing conditions that increase leaf and shoot growth could lead to a priority movement of $\mathrm{Ca}$ toward leaves. Excessive nitrogen fertilization leads to rapid shoot growth. If rapid shoot growth is occurring simultaneous with fruit set and growth, then BER could result, because $\mathrm{Ca}$ is preferentially moved to the growing leaves as opposed to the fruits.

Excess fertilization also can increase the soluble salt concentration in the soil. High soluble salt concentrations in the soil solution near the roots can lead to a diffusion gradient that favors movement of water from a low salt concentration environment (the root) to the high salt environment (the soil solution). This condition makes it more difficult for the root to take up water (and $\mathrm{Ca}$ ).

Inadequate irrigation could predispose the fruits to $\mathrm{Ca}$ deficiency. Water stress leads to a general reduction in $\mathrm{Ca}$ transported in the plant. Since fruits are the least likely to receive ample Ca delivery under the best of conditions, then it follows that expanding fruits will be starved for $\mathrm{Ca}$ under water stress. Inadequate water delivery to the plant could result from several causes. A poorly managed irrigation system, resulting in inadequate water delivery to the plant, is a common underlying cause. Root pruning from mechanical cultivation, diseases, nematodes, or flooding also could reduce water uptake.

\section{Prevention of BER}

Minimizing the likelihood of BER takes a concentrated effort to reduce the conditions that predispose the pepper crop to BER. An understanding of Ca physiology in the plant and why BER might occur is needed before embarking on a management program. For example, knowing that Ca moves in the water stream in the plant, the grower might opt for increasing the level of irrigation instead of applying more $\mathrm{Ca}$ fertilizer.

- Control of BER begins with irrigation and nitrogen fertilizer management. The irrigation system must be designed to be able to supply adequate water especially during those high stress periods of the growing season. Greatest stress occurs during prolonged droughts and when dry winds blow for extended periods.

Technologies and equipment that can monitor soil moisture should be employed by growers. Growers should strive for uniform soil moisture during the day and night. This might mean more irrigation during the hotter times of the day, especially during the fruit-set phase of crop development.

- Nitrogen fertilizers should not be applied in excessive amounts. High nitrogen rates, whether from chemical fertilizers or excessive manure applications, will lead to proliferation of leaves and branches. Plants with excessive vegetative growth will be most likely to suffer from Ca deficiency in the fruits.

- Growers should have knowledge of their soil and irrigation water $\mathrm{Ca}$ concentrations. If these sources are supplying adequate amounts of $\mathrm{Ca}$, then the grower would not need to supplement the soil $\mathrm{Ca}$ with $\mathrm{Ca}$ fertilizers. Calcium fertilizer materials, 
especially for soluble fertilizers, are typically expensive.

- Foliarly-applied Ca fertilizers are not likely to correct or prevent BER. Ca ions in ample amounts are not actively mobilized from the leaf downward to the fruits.

- Pepper plants need a well prepared soil with no shallow compaction zones that would restrict root growth. Restricted root growth could lessen that plant's ability to find water under dry soil conditions. Control of any factors that can damage roots is important for controlling BER. Root diseases, nematodes, and flooding should be controlled.

- Using polyethylene mulches, black under cool spring seasons and silver or white-on-black in the summer or fall seasons will moderate the soil temperature leading to more optimum root function and water uptake, which leads to improved $\mathrm{Ca}$ uptake.

- Sometimes multiple factors contribute to the development of BER. For example, a crop that is highly vegetative from excessive nitrogen would be more likely to suffer from water stress under dry weather conditions or inadequate irrigation. Although the irrigation program might be adequate early in the plant growth cycle, there could be short-term water stress and BER as the plants reach full size and are setting and enlarging fruits.

\section{Conclusion}

Blossom-end rot is not always a straightforward fruit disorder, in either cause or prevention. Growers should understand $\mathrm{Ca}$ nutrition and physiology in the soil and pepper plant. This knowledge is the key to preventing the conditions that predispose pepper crops to BER. Two of the major factors, under grower control, that minimize the chances for BER, are proper nitrogen fertilization and optimum irrigation management.

\section{Reference:}

Mengel, K., and E. A. Kirkby. 1982. Principles of Plant Nutrition. 3rd edition. International Potash Institute, Bern, Switzerland. 